\title{
GRADIENTS OF THE INTERGENERATIONAL TRANSMISSION OF HEALTH IN DEVELOPING COUNTRIES
}

\author{
Sonia Bhalotra and Samantha Rawlings*
}

\begin{abstract}
This paper investigates the sensitivity of the intergenerational transmission of health to changes in the socioeconomic and public health environment into which children are born using individual survey data on 2.24 million children born to 600,000 mothers during the period 1970 to 2000 in 38 developing countries merged by country and cohort with macroeconomic data. We find that children are more likely to bear the penalty exerted by poor maternal health if they are conceived or born in adverse socioeconomic conditions. Equivalently, shocks to the child's birth environment are more damaging of children born to women with weaker health at birth.
\end{abstract}

\section{Introduction}

$\mathrm{T}$ HE persistence of disadvantage within families has attracted interest across the social sciences. Even in the United States, the incomes of sons exhibit a strong correlation, estimated at 0.4, with the incomes of fathers (Solon 1992; Corak, 2006). Some of this correlation can plausibly be put down to the heritability of income-enhancing traits such as ability, frailty, or patience, but some of it reflects differences in families' human capital investment. What is of interest for public policy is the extent to which these differences can be narrowed, so that children from unequal families start life with more equal opportunities. Motivated by persistent dramatic inequalities in health across countries (Deaton, 2006), we investigate how the health endowment that children acquire from their mothers interacts with the socioeconomic and public health environment that they are born into. We allow nonlinearity in the levels and gradients, and asymmetry around the country mean of mother's health since it is mobility at the low end of the distribution that is relevant to reducing health inequalities.

Evidence in support of endowment-environment interactions is accumulating (Turkheimer et al., 2003, Moffitt et al., 2005, Cunha \& Heckman, 2007), but few empirical studies explicitly allow for these interactions; indeed, many rely on an absence of interaction for identification. Notable exceptions include Björklund, Lindahl and Plug (2005), Currie and Moretti (2007), and van den Berg, Doblhammer, and Christensen (2008).

Received for publication August 6, 2009. Revision accepted for publication September 9, 2011.

* Bhalotra: University of Bristol; Rawlings: University of Reading.

We received helpful comments from Tobi Klein, Jon Temple, Christine Valente, Frank Windmeijer, and participants at the meetings of the North Eastern Universities Development Economics Conference (Boston), Health Economics and Econometrics workshop (Sardinia), European Economic Association (Barcelona), European Society of Population Economics (Seville), the annual CEDI conference Brunel (London), the Riccardo Faini Conference on Development Economics (Italy), and seminars at UC Dublin, Nottingham, the Public Health Foundation of India, the Indian Statistical Institute, and the International Growth Centre India policy conference. We are grateful to Alex Barr for his excellent assistance in setting up the data and to the CMPO for funding his internship.

A supplemental appendix is available online at http://www.mitpress journals.org/doi/suppl/10.1162/REST_a_00263.
Health is a multidimensional latent variable that is notoriously difficult to measure. We use height as a measure of the mother's health in view of the little tested hypothesis that it is the stock of the mother's health at the birth of a child that matters (Barker, 1997) rather than, as commonly assumed, her health during pregnancy. There is considerable nongenomic variation in adult heights, some of it determined by the health environment in their childhood (Bozzoli, Deaton, \& Quintana-Domeque, 2009). We use infant mortality risk as an (inverse) indicator of child health as this is sensitive to the prevalence of infectious disease and poor nutrition (Black and Morris, 2003; Bozzoli et al., 2009). Since survivors of cohorts that experience high rates of infant mortality tend to be scarred for life, exhibiting shorter stature (Bozzoli et al., 2009; Bhalotra, 2008), higher adult morbidity, and earlier mortality (Elo \& Preston, 1992; van der Berg, Lindeboom, \& Lopez, 2006), any improvements in mother's health or the child's birth environment that show an impact on infant mortality will also have potential long-run consequences.

We assemble a data set of unprecedented scope in this literature, with comparable data on 2.24 million children born to 600,000 mothers in 38 developing countries in the period 1970 to 2000 . The microdata are derived from fertility histories, so children are naturally linked to biological mothers, avoiding the problem common in cross-sectional surveys of the presence of nonbiological children, which, in Africa, is empirically important given the prevalence of orphanhood and child fostering (Case, \& Paxson, and Ableidinger 2004; Isiugo-Abanihe, 1985). These data are merged by the index child's cohort and country of birth with country-level time series data that contain information on income and public health provision. The estimation sample thus contains panels of births within mother nested in a country-year panel, and we are able to control for unobserved heterogeneity at the mother and the country-year level. We also estimate the population-averaged effects from a more general model in which mother-level unobserved heterogeneity is allowed to interact with the regressor of interest.

Mother fixed effects sweep out the additive effects of genetic and nongenetic endowments inherited from the mother and shared by siblings. Previous studies tend to use data on sisters or twin sisters of the mother or else on adopted children (Behrman \& Rosenzweig, 2002; Plug, 2004; Royer, 2009; Currie \& Moretti, 2007) and so they are only able to purge the mother's genetic endowments (see section IIC). The reason that previous studies have not exploited data on siblings or twin children is not only that these data are often scarce but also because this would involve throwing away the baby with the bathwater. The indicator of mother's education or health is typically a timeinvariant mother-specific variable (like years of schooling or 
birth weight) that would be absorbed by the mother fixed effects. This is the case in our specification as well: the main effect of height is not identified. However, its gradient in the health environment is. The identifying variation is generated by siblings being born at different times and hence in potentially different environments.

The main analysis provides (the first) estimates of the extent to which changes in income growth, mother's education, and public health services weaken the intergenerational transmission of health, the main effects of these variables being absorbed by country-year fixed effects. In order to describe the impact of longer-run economic growth on health mobility, we also investigate whether the change in the intergenerational health coefficient between cohorts separated by two decades differs in countries that recorded positive growth than in countries that experienced stagnation or negative growth. This quasi-experiment is possible on our data because of the sharp diversity of the growth experiences of developing countries in the past three decades. Of the 38 in the sample, only 14 experienced significant positive growth over the period, 9 countries exhibited significantly negative growth, and the remaining 15 had average growth rates insignificantly different from zero.

Here is a summary of the main findings. The levels model shows considerable intergenerational persistence in health. Across a vast sample of developing countries, mother's stature exhibits a substantial negative influence on infant mortality conditional on family and country living standards. A 1 standard deviation $(7.13 \mathrm{~cm})$ gain in mother's height is associated with close to a $0.73 \%$ point reduction in infant mortality risk, which is about $7.6 \%$ of the average mortality rate in the sample. The penalty associated with being born to a relatively short mother is greater than the gain associated with having a relatively tall mother, and the penalty is increasing in the deviation of mother's height from the country mean.

The intergenerational correlation exhibits a steep gradient in income, mother's education, and public health in the fetal and birth years. These gains are in general stronger for children who are initially relatively disadvantaged by being born of mothers with weaker health. This is consistent with mothers' health acting as a shock absorber. If we think of the mother's health at the birth of her child as a baseline investment in the health of her child, this finding is consistent with economic models of health production in which diminishing marginal productivity implies that a shock of a given size has a greater impact on children with lower baseline investments (Heckman, 2007; Almond \& Currie, 2010).

The effects are sizable. An extra year of education among mothers of children in the country and cohort of the index child lowers the intergenerational correlation of health by $17 \%$. The attenuation of the correlation associated with 1 standard deviation increases in log per capita GDP and immunization rates, respectively, is about $20 \%$ and $18.5 \%$ respectively. The interaction coefficients are enlarged on controlling for mother-level unobserved heterogeneity. We identify some heterogeneity in the treatment effect by mother characteristics, but this appears not to be significantly correlated with the treatment (her height or her height interacted with indicators of the SES environment). The alternative specification designed to capture longer-run change shows that between the early 1970s and the early 1990 s, the intergenerational correlation rose more rapidly in countries with negative growth.

\section{A. Relation to Previous Literature}

A cross-disciplinary literature documents the impact on intrauterine growth retardation of poor maternal health during pregnancy, measured as smoking, alcohol consumption, stress, infection, or nutritional deprivation (Kramer, 1987; Almond, 2006; Camacho, 2008; Cogswell, Weisberg, \& Spong, 2003). We differ in studying how the mother's health stock, accumulation of which begins in her childhood, influences the health of the next generation. There is some epidemiological evidence that mothers exposed to adverse conditions in their childhood tend to show reduced weight gain and increased risk of developing hypertension during pregnancy (Hackman, van Belle, \& Daling, 1983, Klebanoff et al., 1999; Drake \& Walker, 2004), factors that predispose them to having low-birth-weight babies (Cawley, Mckeown, \& Record, 1954; Currie \& Moretti, 2007). Infection in early life tends to result in women failing to attain the height predicted by their genetic potential (Deaton, 2007; Bhalotra, 2008; Bozzoli, et al., 2009). They then tend to have reduced uterine and ovarian size, which predicts lower birth weight (Ibanez et al., 2000), lower height for age, and weaker survival chances of their offspring (Strauss \& Thomas 1990; Venkataramani, 2011). We investigate infant mortality rather than birth weight, which is useful since the presence of causal effects of birth weight on subsequent health is controversial (Almond, Chay, \& Lee, 2005). More important, we depart from most previous work in considering whether improvements in the contemporary health environment can rectify for the current generation the legacy of poor environmental conditions in the childhood of the previous generation.

The economics literature on intergenerational persistence has focused on education as the element of human capital that drives earnings (Ahlburg, 1998; Grawe \& Mulligan, 2002; Black \& Devereux, 2010). In fact child health influences later life health and socioeconomic status (SES) (Barker, 1997; Case, Fertig, \& Paxson, 2005; Almond, 2006; Smith, 2009), and these in turn influence the health of the next generation (Case, Lubotsty, \& Paxson, 2002, Currie, 2009). In this way, intergenerational persistence in health may mediate intergenerational persistence in SES. There is only a small literature on intergenerational health in economics and an even smaller literature linking it to SES (Currie, 2009). We focus on the extent to which socioeconomic conditions mediate the intergenerational trans- 
mission of health. Numerous studies estimate the influence on child health of either family (SES) or mother's health, but far fewer have investigated an interaction of the two. Exceptions include Conley and Bennett (2001), Currie and Moretti (2007), van den Berg et al. (2008), and, implicitly, Almond and Chay (2006). Our estimates also contribute to the literature on income and health. By allowing the influence of income on child health to vary with the mother's health, we engage the possibility that even where its average effect is small (Cutler, Deaton, \& Lleras-Muney, 2006; Deaton, 2006), income may have large effects at some place in the distribution of mother's health.

Epidemiological research has relied on small samples, and no previous work in economics has analyzed crosscountry microdata on this scale or attempted to analyze time-varying covariates using cohorts across a period like three decades. We provide the first systematic evidence of gradients for developing countries and, indeed, the first cross-country evidence in the wider domain (see Solon, 2002). The focus on developing countries is pertinent given the wide prevalence here of poor maternal health (documented in Bhalotra \& Rawlings, 2011), low SES, and weak public health provision. Poor (adult) health lowers labor market productivity, as well as the productivity of mothers' time in the production of child health. ${ }^{1}$ Given diminishing marginal returns, these tendencies are stronger at the lower levels of health evident in poorer countries (Steckel, 1986; Fogel, 1994; Thomas \& Strauss, 1997; Dasgupta \& Ray, 1987; Schultz, 2005). Although the potential for ill health to generate poverty traps at the household and country level has been recognized (Steckel, 1986; Dasgupta \& Ray, 1987; Schultz, 2005), evidence of underlying mechanisms and, especially, of the role of intergenerational health transmission is scarce.

The rest of this paper unfolds as follows. Section II sets out the methodology, section III discusses the results and potential mechanisms, and section IV concludes.

\section{Data and Methodology}

We assemble microdata from the Demographic and Health Surveys for a sample of 38 countries for which women's heights are recorded (table 1). Details concerning the sample and variable construction are in the online appendix. Here we say a few words about heights. Heights are measured by trained surveyors who use similar measurement devices across the 77 surveys, which is relevant

\footnotetext{
${ }^{1}$ Poor health may make mothers less responsive to symptoms of infection, less able to breastfeed, or challenge energies available for routine tasks (Basu, 1997) and so limit uptake of public services relevant to child health, for instance, because mothers may have to travel long distances to access a health center or make several visits because of staff absenteeism (Chaudhury et al., 2006).

Consistent with the importance of maternal time inputs to child health, business cycle variation in mother's disposable time has been shown to influence health-seeking behaviors and infant mortality (Dehejia \& Lleras-Muney, 2004; Bhalotra, 2010b; Miller \& Urdinola, 2010).
}

since measures of self-reported height have been shown to bias downward estimates of the heritability of height (Macgregor et al., 2006). Previous studies of intergenerational health transmission have tended to use mother's birth weight, which is thought to reflect the health environment in the critical period between conception and birth (Currie \& Moretti, 2007). Adult height is correlated with birth weight (Emmanuel et al., 1992; Costa, 1998), but arguably is a better measure of long-term health as it captures any catch-up after birth while also incorporating the cumulative impact of health shocks between birth and the end of the growth period (Cole, 2000; Strauss \& Thomas, 2008; Bozzoli et al., 2009; Akresh et al., 2012). Height is a particularly good signal of health at lower standards of living where nutrition is scarce and the extortions of infectious disease are greater (Costa, 1998; Fogel, 1994; Steckel, 1995) and it is predictive of life expectancy (Galton, 1886; Waaler, 1984).

The intergenerational transmission of health involves both genomic and nongenomic mechanisms, and the challenge in studies that seek to estimate the levels correlation lies in isolating the nongenomic from the genomic. Although we present the (total) levels correlation to establish a baseline, we are interested here in how that correlation tilts with socioeconomic change. It seems plausible that the genomic part of the correlation is invariant to the external environment and hence that gradients identified from shocks to the external environment reflect nongenomic processes. We nevertheless control for the additive influence of inherited endowments on infant survival with mother fixed effects. Our identification strategy was summarized in section I. The rest of this section details the estimated specifications.

\section{A. The Levels Model: Pooled and Country-Specific Estimates}

The levels model estimates the intergenerational correlation of health:

$$
c_{i m j t}=\alpha_{0}+\beta_{0} h_{m}+\gamma_{0 j t}+e_{0 i m j t} .
$$

The dependent variable, $c$, is a binary variable indicating whether child $i$ born to mother $m$ in country $j$ in year $t$ died by the age of 12 months (infancy). The regressor of interest $h$ is mother's height, and we expect $\beta<0$ since the dependent variable is an inverse measure of child health. The equation also includes child and mother level covariates which we list in section IIF. $\gamma_{0 \mathrm{jt}}$ are country $\times$ year fixed effects. We estimated equation (1) for each of the 38 countries in the sample:

$$
c_{i m j t}=\alpha_{0 j}+\beta_{0 j} h_{m}+\varphi_{0 j t}+\varepsilon_{0 i m j t} .
$$

We work with the pooled regression model in order to investigate gradients of the mother-child transmission of health with respect to country-time varying variables. 
TABle 1.-Country Details

\begin{tabular}{|c|c|c|c|c|}
\hline Country & $\begin{array}{l}\text { GDP Growth, } \\
1970-2000\end{array}$ & $\begin{array}{l}\text { IMR Decline, } \\
\text { 1970-2000 }\end{array}$ & $\begin{array}{l}\text { Potential Range of } \\
\text { Year of Birth of Children }\end{array}$ & Interview Dates \\
\hline Benin & 0.103 & $-2.067 * * *$ & $1960-2001$ & 1996, 2001 \\
\hline Brazil & $1.367 * *$ & $-4.220 * * *$ & $1959-1996$ & 1996 \\
\hline Burkina Faso & $0.955 * *$ & $-2.257 * * *$ & $1955-2003$ & 1992-1993, 1998-1999, 2003 \\
\hline Central African Republic & $-0.927 * *$ & $-1.427 * *$ & $1958-1995$ & 1994-1995 \\
\hline Cambodia & $-2.275^{* *}$ & $-1.911 * * *$ & $1965-2000$ & 2000 \\
\hline Cameroon & 0.682 & $-1.311 * * *$ & $1960-2004$ & 1998,2004 \\
\hline Chad & -0.044 & $-1.113^{* * * *}$ & 1960-2004 & 1996-1997, 2004 \\
\hline Colombia & $1.781 * *$ & $-4.327 * * *$ & $1958-2005$ & $1995,2000,2004-2005$ \\
\hline Comoros & -0.312 & $-3.389 * * *$ & 1961-1996 & 1996 \\
\hline Cote d'Ivoire & 0.123 & $-2.056 * * *$ & $1956-1999$ & 1994, 1998-1999 \\
\hline Dominican Republic & $2.277 * *$ & $-3.281 * * *$ & $1952-1996$ & 1991,1996 \\
\hline Egypt & $3.126^{* *}$ & $-5.316^{* * *}$ & 1954-2005 & 1992-1993, 1995-1996, 2000, 2005 \\
\hline Ethiopia & $1.018 * *$ & $-3.554 * * *$ & $1955-1997$ & 2000,2005 \\
\hline Gabon & $-1.722 * *$ & $-2.634 * * *$ & $1962-2000$ & $2000-2001$ \\
\hline Ghana & 0.188 & $-2.000 * * *$ & $1957-2003$ & 1993-1994, 1998-1999 \\
\hline Guinea & -0.098 & $-2.223 * * *$ & $1961-2005$ & 1999,2005 \\
\hline Haiti & -0.120 & $-3.752 * * *$ & $1957-2000$ & $1994-1995,2000$ \\
\hline Honduras & $0.471 * *$ & $-3.783 * * *$ & 1969-2006 & $2005-2006$ \\
\hline India & $2.831 * *$ & $-3.070 * * *$ & $1961-2000$ & 1998-2000, 2005-2006 \\
\hline Kenya & $0.338 * *$ & $-0.980 * *$ & $1954-2003$ & 1993,2003 \\
\hline Lesotho & $2.889 * *$ & $-1.366^{* *}$ & $1967-2005$ & 2004-2005 \\
\hline Madagascar & $-1.860 * *$ & -1.027 & $1962-2004$ & $1997,2003-2004$ \\
\hline Malawi & $1.210^{* *}$ & $-1.913 * * *$ & $1954-2005$ & $1992,2000,2004-2005$ \\
\hline Mali & $1.557 * *$ & $-2.226 * * *$ & $1960-2001$ & $1995-1996,2001$ \\
\hline Morocco & $1.659 * *$ & $-4.319 * * *$ & $1953-2004$ & $1992,2003-2004$ \\
\hline Mozambique & -0.270 & $-1.437 * * *$ & $1960-2004$ & $1997,2003-2004$ \\
\hline Namibia & -0.139 & $-1.791 * *$ & $1957-1992$ & 1992 \\
\hline Nicaragua & $-2.984 * *$ & $-5.453 * * *$ & $1961-2001$ & 1997-1998, 2001 \\
\hline Niger & $-0.931 * *$ & $-2.299 * * *$ & $1954-1998$ & 1992,1998 \\
\hline Peru & $-0.964 * *$ & $-4.473 * * *$ & $1956-2000$ & $1991-1992,2000$ \\
\hline Rwanda & -0.688 & 0.052 & $1963-2005$ & 2000,2005 \\
\hline Senegal & -0.091 & $-1.805^{* * *}$ & $1954-2005$ & $1992-1993,2005$ \\
\hline Tanzania & 0.353 & $-0.856^{* * * *}$ & $1953-2005$ & 1991-1992, 1996, 2004-2005 \\
\hline Togo & $-1.965 * *$ & $-2.516^{* * * *}$ & $1958-1998$ & 1998 \\
\hline Turkey & $2.068 * *$ & $-5.598 * * *$ & $1957-1998$ & 1993,1998 \\
\hline Uganda & -0.492 & $-1.095 * * *$ & 1959-2001 & $1995,2000-2001$ \\
\hline Zambia & $-1.861 * *$ & 0.372 & $1954-2002$ & $1992,1996-1997,2001-2002$ \\
\hline Zimbabwe & -0.057 & -0.311 & 1957-1999 & 1994,1999 \\
\hline
\end{tabular}

three it is 16 . The growth rate of $x$ is the estimated coefficient from a regression of $x$ on a linear trend. Growth rates are reported in percentages. Significant at $* * 5 \%$, *** $1 \%$.

\section{B. The Gradients Model}

The levels model is extended to allow mother or country level measures of the socioeconomic environment $\left(y_{m}\right.$ and $y_{j t}$, respectively) at the birth of the child to interact with mother's height:

$$
\begin{aligned}
& c_{i m j t}=\alpha+\beta h_{m}+\tau\left(h_{m} \times y_{m}\right)+\gamma_{j t}+\chi y_{m}+e_{i m j t}, \\
& c_{i m j t}=\alpha+\beta h_{m}+\tau\left(h_{m} \times y_{j t}\right)+\gamma_{j t}+e_{i m j t} .
\end{aligned}
$$

The intergenerational correlation is now $(\partial c / \partial h=\beta+$ $\tau \times y)$ and its gradient with respect to changes in the early life environment is $\tau .^{2}$ We expect $(\partial c / \partial y<0)$ and since $\beta$ $<0$, we expect $\tau>0$. Country-year fixed effects $\gamma_{j t}$ comprehensively and flexibly capture the main effects of $y_{j t}$.

\footnotetext{
${ }^{2}$ We focus on the more plausibly exogenous country-level indicators. We nevertheless report results using mother-level socioeconomic status (as done in Currie \& Moretti, 2007) so as to assess the coefficient on the average education of mothers in a birth cohort against that of the individual education of mothers. For convenience, we use the same Greek letters for parameters in equations $(2 a)$ and $(2 b)$
}

They also control for rainfall shocks, oil price changes, war, famine, or medical technological progress that may simultaneously influence both $c$ and $y$. They absorb country- and cohort-specific mean height, taking care of the fact that being $1.6 \mathrm{~m}$ tall in Kenya where women are taller on average may not confer the advantage it does in India, where women are shorter. Since mean height varies with ethnicity within country, we explore the robustness of the estimates to including controls for ethnicity and, in a variation that incorporates more observations, dummies for subregion within country.

The family SES measures $y_{m}$ are mother's and father's education and urban location. For a given height, we expect a stronger correlation of mother-child health among less educated women given that education has a positive causal effect on healthy behaviors (Currie \& Moretti, 2003; Cutler $\&$ Lleras-Muney, 2006) and a negative effect on fertility (Osili, 2008). The country-cohort indicators $y_{j t}$ are GDP, the average education of mothers in the country, and year of birth of the index child and immunization rates, which indicate the quality of public health provision (UNICEF, 2009). These choices are motivated by Grawe (2004) and 
Solon (2004), who extend the Becker and Tomes (1979, 1986) model of mobility to incorporate credit constraints and progressive public expenditure, respectively. Conditional on mother's height and country-year fixed effects, GDP will reflect business cycle fluctuations in the fraction of constrained households (Koren \& Tenreyo, 2007) and procyclicality in public services relevant to child survival (Paxson \& Schady, 2005; Bhalotra, 2007). Changes in immunization coverage will capture the influence of immunity to infectious disease, the main cause of child death in developing countries (Cutler, Miller, \& Norton, 2007; UNICEF, 2009).

Our sample contains massive variation in socioeconomic conditions within country and mother. Income volatility in developing countries is endemic (Pritchett, 2000; Malik \& Temple, 2009). Public health provision is similarly volatile, being influenced not only by income volatility (Paxson \& Schady, 2005; Bhalotra, 2007) but also by war and natural disasters that may destroy health infrastructure or impede implementation of interventions such as WHO immunization campaigns. Variation in education within mother arises because we use the country average of the education of all mothers giving birth in the year of the index birth.

Estimation of direct effects of income and education of parents on child health in the wider literature has been challenged by the play of correlated family-level unobservables, and causal estimates are scarce (Currie, 2009). We avoid this problem by modeling SES shocks at the country-cohort level while controlling for mother-level unobserved heterogeneity. A few previous studies similarly use plausibly exogenous business cycle variation in income (van den Berg et al., 2006; Bhalotra, 2010b), but they do not interact income with mother's health, which we find is important.

\section{Gradients within Mother}

We extend the model to include mother fixed effects, $\alpha_{m}$ :

$$
c_{i m j t}=\alpha_{m}+\tau_{1}\left(h_{m} \times y_{j t}\right)+\delta y_{j t}+z_{i}^{\prime} \lambda+\gamma_{t}+\theta_{j} t+u_{i m j t} .
$$

Since mother's height does not vary across her births, the main effect of height is absorbed by $\alpha_{m}$, and $\beta$ is no longer identified but $\tau_{1}$ is. The $\alpha_{m}$ sweep up all mother-level variables, including the genetic endowments that she transmits to her offspring. ${ }^{3}$ The parameter $\delta$ indicates the direct influence of $y$ on child health by comparing siblings born into different environments, and $\tau_{1}$ indicates how the size of this effect varies with the mother's stature. Mother fixed effects estimation creates a possible conflation of calendar time effects with the effects of birth order or of age of the mother

\footnotetext{
${ }^{3}$ They also sweep up genetic and other fixed traits of the father as long as he is common across siblings, the permanent income of the family, local climate, the mother's efficiency in producing child health, her preferences for health, and physiological characteristics such as pelvic size that may constrain a small woman to produce a small child.
}

at birth, but these variables are held constant in $z$. Country fixed effects are implied by mother fixed effects, as mothers do not migrate between countries, and the equation includes year fixed effects and country-specific trends.

As indicated in section I, previous work has used mothers who are twins or sisters to isolate intergenerational correlations conditional on inherited traits (Currie \& Moretti, 2007; Behrman \& Rosenzweig, 2002). This approach has two weaknesses, which the use of mother fixed effects resolves when interest is in the gradient rather than the level of the intergenerational correlation (see section I). First, it fails to purge the influence of father's endowments (sisters will marry different men, but siblings will have the same father), time-invariant aspects of the child's family environment, and nonbiological endowments. An instance of relevant nonbiological endowments in the context of education is mothering ability (Plug, 2004). ${ }^{4}$ In the context of health, it may include physiological changes incurred by the mother as a consequence of her childhood environment that may be transmitted to her births and yet not shared with her sisters (section IA). A second weakness of the existing approach is that differences in human capital between mothers who are twins or siblings are likely to be small and endogenously determined by parental choices (Bound \& Solon, 1999).

The other identification strategy in the education literature involves using school reforms to instrument mother's school years (Chevalier, 2003; Currie \& Moretti, 2003; Black, Devereux, \& Salvanes, 2005). A natural analogue may be to instrument mother's height with events like famines or epidemics in her childhood, but these instruments are unlikely to be valid (Heckman, 2000; Deaton, 2010). This is a reflection of the impossibility of finding a comprehensive index of (mother's) health. ${ }^{5}$

\section{Asymmetry and Nonlinearity}

Equations (1) to (3) are reestimated replacing height in meters with dummies for standardized height indicating whether the mother is $1 / 2,1$, or 2 standard deviations above or below the mean height in her country. This allows the response to mother's height to be heterogeneous in the mother-specific level of height, consistent with diminishing returns in the child health production function and an upper bound to survival chances. If we think (crudely) of mother's height as a treatment, then we may think of deviations of her height from the mean as treatment intensity. Using $k=$ 1 to 6 to indicate the six height dummies, equations (2b)

\footnotetext{
${ }^{4}$ The strategy of using data on adoptee children (Sacerdote, 2002) is also subject to the play of nonbiological endowments (Plug, 2004).

${ }^{5}$ The difference with education is not that years of schooling are a perfect proxy for cognition (they are not) but rather that the instrument is narrowly tailored to influence schooling and nothing else, so that the exclusion restriction holds. In contrast, events in the mother's childhood can plausibly influence child survival conditional on her height (evidence of this, which includes the sample used in this paper, is in Bhalotra, 2010a).
} 
and (3) can be written as follows (we estimate the analogous form for equation [2a], though this is not displayed):

$$
\begin{aligned}
& c_{\text {imjt }}=\alpha+\beta_{k} h_{k m}+\tau_{k}\left(h_{k m} \times y_{j t}\right)+\gamma_{j t}+e_{i m j t}, \\
& c_{\text {imjt }}=\alpha_{m}+\tau_{1 k}\left(h_{k m} \times y_{j t}\right)+\delta y_{j t}+z_{i}^{\prime} \lambda+\gamma_{t}+\theta_{j} t+u_{\text {imjt }} .
\end{aligned}
$$

This specification naturally allows asymmetry in the level and gradient coefficients around the (country) mean of height. Gradient heterogeneity indicates where, along the distribution of maternal health, improvements in early life conditions are most effective.

\section{E. The in Utero Environment}

Recall that the dependent variable, infant mortality, refers to the first year of life. For this reason, $y_{j t}$ is measured for the year of birth of the child. In view of evidence that fetal development is sensitive to the health and SES environment (Almond \& Currie, 2010), we explore an alternative specification that replaces $y_{j t}$ with its first lag. This extends the "fetal origins" literature (Almond \& Currie, 2010) by explicitly allowing mother's health to mediate the impact of the external environment on the fetus.

\section{F. Heterogeneity and Population-Averaged Effects}

We have allowed heterogeneity in the impact of mother's height on infant survival by (a) country (equation [1a]); (b) mother's height $\left(h_{k m}\right)$, and (c) indicators $\left(y_{m}, y_{j t}\right)$ of the early life environment and by both $\mathrm{b}$ and $\mathrm{c}$ at once (see equations [4a] and [4b]). We also investigate slope heterogeneity by mother-level covariates. Let mother-level unobserved heterogeneity, $v_{m}$, interact with the covariate of interest. In the levels model, this generates $\beta_{m}=\beta+\pi v_{m}$. In the gradients models, where the covariate of interest is $\left(\partial c_{i m j t} / \partial h_{m}=\beta+\tau, y_{j t}\right)$, it generates $\beta_{m}=\beta+\pi v_{m}$ and $\tau_{m}=$ $\tau+\phi v_{m}$. The mother fixed effects model, equation (3), is a within-groups specification on panel data where the panel is of births sequenced within mother, and the usual fixed effects estimator applied to a linear model identifies the average $\tau_{1}$ in the presence of individual slopes as long as the slopes are mean independent of the time demeaned covariates (the individual slopes are allowed to be correlated with the time-constant features of the covariates; see Wooldridge, 2005a). In the specification that omits mother effects but includes country-year fixed effects, there remains crosssectional variation across mothers within country-year. To identify $\beta$ in this model, we assume that $v_{m}$ is independent of $h_{m}$ conditional on a vector of observables $x_{m}$. ${ }^{6}$ This is the commonly invoked ignorability assumption, and it is consid-

\footnotetext{
${ }^{6}$ The covariates, $x_{m}$ are now indicators for maternal age at index birth, the years of education of the mother and father, urban versus rural residence, religion, and mother-level averages of the child-level variables, gender, birth order, and birth month.
}

erably weaker than the assumption that $v_{m}$ is independent of $h_{m}$ in the unconditional model. We extend the model to include the vector $x_{m}$ and interactions of mean deviations of each element of $x_{m}$ with $h_{m}$ and $h_{m}, y_{j t}$. Ordinary least squares estimates of the uninteracted coefficients $\beta$ and $\tau$ then consistently identify the average population effect or, when $h$ is a set of binary indicators $\left(h_{k m}\right)$, the average treatment effect for any specified $y_{j t}$ at the mean of mother's characteristics (Wooldridge, 2002, 2005b). ${ }^{7}$

\section{G. Economic Development over the Long Run}

In a variation intended to capture the full impact of longer-run economic development on the intergenerational coefficient (see section I), we investigate whether the intergenerational correlation declined faster in countries with positive economic growth than in other countries.

\section{H. Estimation}

We estimate linear probability models (LPM). Marginal effects from logits and probits are almost identical to the LPM coefficients, and the LPM predictions lie predominantly within the $[0,1]$ interval; no predictions exceed unity, and only $1.3 \%$ of predictions are negative. Excluding the observations that generate negative predictions does not alter the estimated coefficients. The standard errors are robust to arbitrary forms of heteroskedasticity and clustered by country to allow autocorrelation within country (Bertrand, Duflo, \& Mullainathan, 2004). Since mothers are plausibly assumed not to migrate across countries between births, this naturally also allows sibling correlations.

\section{Results}

\section{A. Unconditional Nonparametric Estimates}

Refer to the lowess plots in figures 1 and 2. Infant mortality risk declines in mother's height until about the mean height in the sample, after which it levels out. Mother's height and infant survival are more closely tied for shorter than for taller women, and there is greater cross-country variation in infant survival among children of shorter women. Since socioeconomic conditions vary but there is no a priori reason for endowment effects to vary systematically across countries, this is suggestive of larger SES effects on the gradient for shorter women. The following section investigates this more carefully, conditioning on the level effects of SES and on country-year unobservables.

\footnotetext{
${ }^{7}$ Consider equation (1) augmented to allow unobserved heterogeneity in levels and in the slope coefficients. The conditional expectation function in the linear model can be written as $E\left(c_{i m j t} \mid h_{m}, v_{m}\right)=\eta+\beta h_{m}+$ $v_{m}+\gamma h_{m} v_{m}$. The ignorability assumption implies $\mathrm{E}\left(v_{m} \mid h_{m}, x_{m}\right)=E\left(v_{m} \mid x_{m}\right)$. It follows that $E\left(c_{i m j t} \mid h_{m}, x_{m}\right)=\eta_{l}+\beta h_{m}+E\left(v_{m} \mid x_{m}\right)+\gamma h_{m} E\left(v_{m} \mid x_{m}\right)$. In the linear case, $E\left(v_{m} l x_{m}\right)=\left(x_{m}-X\right) \delta$, where $X=E\left(x_{m}\right)$, and this is proxied by the sample means of $x_{m}$.
} 
Figure 1.- Infant Mortality against Mother's Height: Lowess Predictions

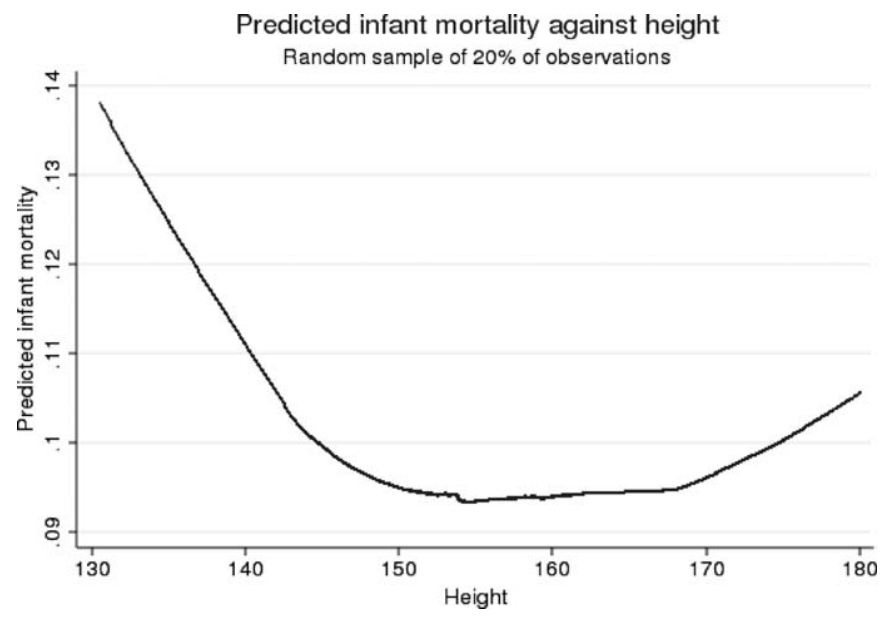

Since infant mortality is recorded as a discrete variable $(0 / 1)$, we obtained a continuous prediction of individual risk from a nonparametric (lowess) regression and plotted this against mother's height. As lowess on the full sample is computationally intensive, this graph was estimated using a random sample of $20 \%$ of observations. The density of observations in the lowess graph is as follows: the 10th, 25 th, 50th, 75th, and 95th percentiles of height are $1.468 \mathrm{~m}, 1.510 \mathrm{~m}, 1.558 \mathrm{~m}, 1.606 \mathrm{~m}$, and $1.679 \mathrm{~m}$, respectively.

\section{B. Levels Model: The Intergenerational Correlation of Health}

A 1 standard deviation $(7.13 \mathrm{~cm})$ gain in mother's height is associated with a $0.73 \%$ point reduction in infant mortality risk, which is $7.6 \%$ of the average mortality rate in the sample (see table 2). Removing controls for family education and demographics raises the intergenerational correlation by $45 \%$. This provides an indication of the extent to which the intergenerational correlation is correlated with SES. Below we investigate SES gradients of the intergenerational correlation. The estimated $\beta$ is robust to conditioning on ethnic or subregion dummies, but since these controls entail a loss of observations, they are not included in further specifications.

Country-specific estimates (equation [1a]) show that the intergenerational coefficient is significant in 28 of 38 countries, with marginal effects ranging between -0.158 in Rwanda and -0.044 in Turkey. ${ }^{8}$ The means of the estimated $\beta_{j}$ with and without weights for the number of births in each country sample are -0.102 and, -0.093 , respectively, close to the point estimate of $\beta$ from the pooled regression, -0.103 . A nonlinear specification of height (table 3 ) reveals that the intergenerational correlation of health increases in moving from mean height toward both tails of the height distribution and that it is larger at the left than at the right tail. This is consistent with constraints binding for women in poor health. Stronger levels effects at the lower end of the mother's height distribution may to some extent be mechanical, as the outcome indicates the poor health of the child. This is not so for gradient asymmetry, since the gradients are conditional on the main effect of mother's height.

\footnotetext{
${ }^{8}$ These estimates are in the online appendix of Bhalotra and Rawlings (2011), available at http://www.efm.bris.ac.uk/ecsrb/bhalotra.htm.
}

Figure 2.-Country-Specific Plots of Infant Mortality against Mother's Height: Lowess PREDictions

Predicted infant mortality against height 38 Developing Countries

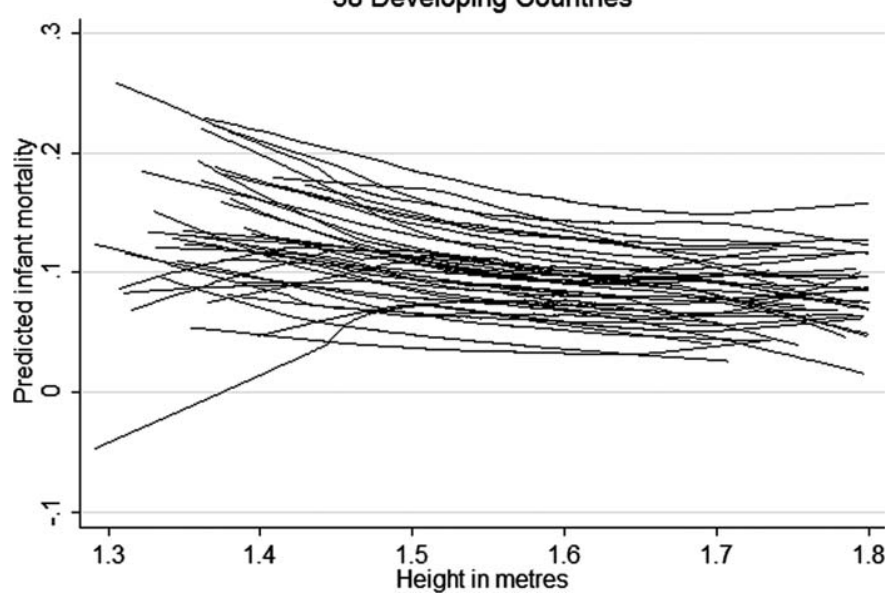

C. Gradients of the Intergenerational Correlation of Health

We first describe how the birth year environment modifies the intergenerational correlation and then discuss in utero conditions. We consistently display both the linear and nonlinear specifications of height. For aggregate measures of early life conditions, we report estimates with and without mother fixed effects. Including mother fixed effects makes the coefficients on the interaction terms (gradients) considerably larger by a factor of between 2 and 4, but as the standard errors also rise, they are not significantly different from the coefficients in equations without the fixed effects.

Larger point estimates in the mother fixed effects models may indicate parental investments that reinforce endowments (Almond \& Currie, 2010). Cross-sectional evidence consistent with reinforcing behavior is in Datar, Ghosh, and Sood (2007) and more indirect evidence that parents consciously differentiate investments in their offspring is captured in the finding that infant deaths in recessions are concentrated among girls rather than their brothers in developing countries (Bhalotra, 2010b; Baird, Friedman, \& Schady, 2011). Alternatively they may signal that estimates unconditional on fixed effects incorporate compositional effects generated by unobserved heterogeneity in responses to shocks. For example, income shocks tend to generate changes in the composition of mothers giving birth (Dehejia \& Lleras Muney, 2004; Bhalotra, 2010b).

Socioeconomic status of the individual mother. This is measured using, one at a time, mother's years of education, an indicator for whether she has at least secondary education and lives in an urban location, and the years of education of her partner (table 4). To the extent that the mother's education does not change once she initiates fertility, her education (recorded at the time of the survey) will reflect her SES at the birth of the child. However, her partnership and location may have changed since the index birth. We therefore focus on interactions with mother's education, 
GRADIENTS OF THE INTERGENERATIONAL TRANSMISSION OF HEALTH IN DEVELOPING COUNTRIES 667

Table 2.-Levels Model: Infant Mortality Risk as a Function of Mother’s Height

\begin{tabular}{|c|c|c|c|c|c|c|c|}
\hline & $\begin{array}{c}(1) \\
\text { Country } \times \text { Year } \\
\text { Dummies }\end{array}$ & $\begin{array}{c}\text { (2) } \\
\text { Add Individual } \\
\text { Characteristics }\end{array}$ & $\begin{array}{c}\text { (3) } \\
\text { Add Further } \\
\text { Characteristics }\end{array}$ & $\begin{array}{c}(4) \\
\text { Add Parental } \\
\text { Education }\end{array}$ & $\begin{array}{c}(5) \\
\text { APE }\end{array}$ & $\begin{array}{l}\text { (6) } \\
\text { Control for } \\
\text { Region }\end{array}$ & $\begin{array}{l}\text { (7) } \\
\text { Control for } \\
\text { Ethnicity }\end{array}$ \\
\hline Height & $\begin{array}{l}-0.149 * * * \\
(0.012)\end{array}$ & $\begin{array}{c}-0.133 * * * \\
(0.013)\end{array}$ & $\begin{array}{c}-0.122^{* * * *} \\
(0.011)\end{array}$ & $\begin{array}{c}-0.103 * * * \\
(0.010)\end{array}$ & $\begin{array}{c}-0.103 * * * \\
(0.008)\end{array}$ & $\begin{array}{c}-0.090 * * \\
(0.008)\end{array}$ & $\begin{array}{c}-0.102 * * \\
(0.010)\end{array}$ \\
\hline \multicolumn{8}{|c|}{ Mother's education } \\
\hline Primary & & & & $\begin{array}{c}-0.016^{* * * *} \\
(0.001)\end{array}$ & $\begin{array}{c}-0.016^{* * * *} \\
(0.001)\end{array}$ & $\begin{array}{c}-0.012 * * \\
(0.001)\end{array}$ & $\begin{array}{c}-0.016^{* * * *} \\
(0.001)\end{array}$ \\
\hline Secondary & & & & $\begin{array}{c}-0.027 * * * \\
(0.002)\end{array}$ & $\begin{array}{c}-0.027 * * * \\
(0.002)\end{array}$ & $\begin{array}{c}-0.021 * * \\
(0.002)\end{array}$ & $\begin{array}{c}-0.028^{* * * *} \\
(0.002)\end{array}$ \\
\hline Higher & & & & $\begin{array}{c}-0.026^{* * * *} \\
(0.003)\end{array}$ & $\begin{array}{c}-0.026^{* * * *} \\
(0.003)\end{array}$ & $\begin{array}{l}-0.021 * * \\
(0.003)\end{array}$ & $\begin{array}{l}-0.030^{* * * *} \\
(0.002)\end{array}$ \\
\hline \multicolumn{8}{|c|}{ Father's education } \\
\hline Primary & & & & $\begin{array}{c}-0.008 * * * \\
(0.001)\end{array}$ & $\begin{array}{c}-0.008 * * * \\
(0.001)\end{array}$ & $\begin{array}{c}-0.008 * * \\
(0.001)\end{array}$ & $\begin{array}{c}-0.009 * * * \\
(0.002)\end{array}$ \\
\hline Secondary & & & & $\begin{array}{c}-0.017 * * * \\
(0.002)\end{array}$ & $\begin{array}{c}-0.017 * * * \\
(0.002)\end{array}$ & $\begin{array}{c}-0.018^{* *} \\
(0.001)\end{array}$ & $\begin{array}{l}-0.020^{* * * *} \\
(0.002)\end{array}$ \\
\hline Higher & & & & $\begin{array}{c}-0.020 * * * \\
(0.002)\end{array}$ & $\begin{array}{c}-0.020^{* * *} \\
(0.002)\end{array}$ & $\begin{array}{c}-0.022 * * \\
(0.001)\end{array}$ & $\begin{array}{l}-0.021 * * * \\
(0.003)\end{array}$ \\
\hline Observations & $2,236,121$ & $2,236,121$ & $2,236,121$ & $2,233,720$ & $2,233,720$ & $2,087,247$ & $1,308,424$ \\
\hline
\end{tabular}

Robust standard errors in brackets allow for clustering within country. **Significant at $5 \%, * * * 1 \%$. The dependent variable is 1 if the index child dies in infancy, that is, by the first birthday. The sample is restricted to children born at least 12 months before the date of the survey. Mother's height is in meters. The estimator is the LPM. Incremental changes to the specification are noted in the column head and are cumulative in moving from left to right except that when we control for region and ethnicity dummies, we replace country-time dummies with time dummies and country-specific trends, for computational reasons. APE refers to the specification in which mother-level heterogeneity is investigated, with height interacted with a vector of demeaned $x_{\mathrm{m}}$. The controls in column 2 are gender, religion, and urban residence, and in column 3 , they are birth month, birth order, mother's age at birth. Religion is controlled for by dummy variables for Christian, Muslim, other, no religion, and religion missing. The number of observations changes as we add more controls due to missing data present in these controls. Mean height in the sample is $1.559 \mathrm{~m}$, and the sample infant mortality rate is $9.7 \%$.

Table 3.-Levels Model Generalized to Allow Nonlinear (and ASYMMETRIC) EFFECTS OF HEIGHT

\begin{tabular}{|c|c|c|c|}
\hline & $\begin{array}{c}(1) \\
\text { Linear }\end{array}$ & $\begin{array}{c}(2) \\
\text { Nonlinear }\end{array}$ & $\begin{array}{c}\text { (3) } \\
\text { Nonlinear APE }\end{array}$ \\
\hline Height in meters & $\begin{array}{l}-0.103 * * * \\
(0.010)\end{array}$ & & \\
\hline \multicolumn{4}{|c|}{$\begin{array}{l}\text { Height in deviations from country mean } \\
\text { SD above mean }\end{array}$} \\
\hline Tall (0.5-1 SD) & & $\begin{array}{l}-0.005 * * * \\
(0.001)\end{array}$ & $\begin{array}{l}-0.005 * * * \\
(0.001)\end{array}$ \\
\hline Tall (1-2 SD) & & $\begin{array}{l}-0.006 * * * \\
(0.001)\end{array}$ & $\begin{array}{l}-0.006 * * * \\
(0.001)\end{array}$ \\
\hline Tall $(>2 \mathrm{SD})$ & & $\begin{array}{l}-0.009 * * * \\
(0.003)\end{array}$ & $\begin{array}{l}-0.010 * * * \\
(0.002)\end{array}$ \\
\hline \multicolumn{4}{|l|}{ SD below mean } \\
\hline Short $(0.5-1$ SD) & & $\begin{array}{l}0.005^{* * * *} \\
(0.001)\end{array}$ & $\begin{array}{l}0.005^{* * * *} \\
(0.001)\end{array}$ \\
\hline Short (1-2 SD) & & $\begin{array}{l}0.013 * * * \\
(0.001)\end{array}$ & $\begin{array}{l}0.013^{* * *} \\
(0.001)\end{array}$ \\
\hline Short $(>2$ SD) & & $\begin{array}{l}0.030^{* * *} \\
(0.005)\end{array}$ & $\begin{array}{l}0.028^{* * * *} \\
(0.003)\end{array}$ \\
\hline Observations & $2,233,720$ & $2,233,720$ & $2,233,720$ \\
\hline Mean height & 1.559 & & \\
\hline IMR & 0.097 & 0.097 & 0.097 \\
\hline$\%$ mothers tall (1-2 SD) & & 10.9 & 10.9 \\
\hline$\%$ mothers tall $(>2 \mathrm{SD})$ & & 1.4 & 1.4 \\
\hline$\%$ mothers tall (0.5-1 SD) & & 14.9 & 14.9 \\
\hline$\%$ mothers short (1-2 SD) & & 11.6 & 11.6 \\
\hline$\%$ mothers short $(>2 \mathrm{SD})$ & & 1.3 & 1.3 \\
\hline$\%$ mothers short $(0.5-1 \mathrm{SD})$ & & 16 & 16 \\
\hline $\begin{array}{l}\text { Robust standard errors clustered by col } \\
\text { table } 2 \text {. Controls include family demogr } \\
\text { Column } 1 \text { reproduces column } 4 \text { of table } 1 \\
\text { set of dummies indicating the mother's } \\
\text { Tall (1-2 SD), and Tall ( }>2 \mathrm{SD} \text { ) refer to } \\
\text { standard deviations above mean height, } \\
\text { SD) refer to being between } 0.5 \text { and } 1 \text {, bet } \\
\text { height, respectively. The omitted category }\end{array}$ & $\begin{array}{l}\text { try in brackets. Si } \\
\text { phics, education c } \\
\text { or comparison. In } \\
\text { ace in the height } \\
\text { peing between } 0.5 \\
\text { spectively. Short } \\
\text { een } 1 \text { and } 2 \text {, and g }\end{array}$ & $\begin{array}{l}\text { nificant at } * * 5 \% \text {, } \\
\text { both parents and } \\
\text { olumn } 2 \text {, we repla } \\
\text { istribution of her } \\
\text { and } 1 \text {, between } 1 \\
0.5-1 \text { SD), Short } \\
\text { ater than } 2 \text { standa }\end{array}$ & $\begin{array}{l}* * 1 \% \text { level. See notes to } \\
\text { country } \times \text { year dummies. } \\
\text { e height in meters with a } \\
\text { ountry. Tall }(0.5-1 \mathrm{SD}) \text {, } \\
\text { ind } 2 \text {, and greater than } 2 \\
1-2 \mathrm{SD}) \text { and Short }(>2 \\
\text { d deviations below mean } \\
\text { ns. }\end{array}$ \\
\hline
\end{tabular}

casting the other two specifications as providing indicative checks.

The interaction terms are all positive, upholding the hypothesis that the intergenerational correlation of health is attenuated in educated and urban families. An increase of one year in mother's education reduces the average correlation by 0.006 , which is $5.8 \%$ of the total effect. If the mother has at least secondary education and is urban ( $12.8 \%$ of women), the correlation is reduced by 0.046 , which is $47.9 \%$ of the total effect. The attenuation associated with father's education is insignificant and small. This suggests that the attenuation associated with mother's education has less to do with family income (which is more strongly determined by father's education) and more to do with the primary caregiver accessing or employing information relevant to child health. (The direct effect of father's education on child survival is significant but at most half the size of the direct effect of mother's education.)

Since the education and height of mothers are positively correlated, interactions of her height with her education may simply reflect nonlinearity in the effect of her height. However, we continue to find positively signed interactions when we allow nonlinearity in height (see online appendix table 1). Education gradients are more marked among shorter women. For women between 1 and 2 standard deviations below mean height, an additional year of education reduces the intergenerational correlation by $9.1 \%$ of the estimated total effect, while being urban and educated to at least the secondary level completely nullifies the infant mortality risk associated with being short.

Average education of mothers. Because deficits in health and education may both be influenced by a disadvantaged family background, a concern with the previous specification is that short women who are highly educated are selected on unobservables. We therefore consider how the intergenerational correlation would change if the average (short) woman had an additional year of education, the average being over mothers giving birth in the index year. 
Table 4.-Gradients: Interactions of Mother's Height with Mother's Socioeconomic Status

\begin{tabular}{|c|c|c|c|}
\hline & (1) & (2) & (3) \\
\hline Mother's height & $\begin{array}{c}-0.118^{* * *} \\
(0.010)\end{array}$ & $\begin{array}{c}-0.109 * * * \\
(0.010)\end{array}$ & $\begin{array}{c}-0.114 * * * \\
(0.010)\end{array}$ \\
\hline Height $\times$ Mother's education years & $\begin{array}{l}0.006^{* * * *} \\
(0.001)\end{array}$ & & \\
\hline Height $\times(1$ if mother is educated and urban $)$ & & $\begin{array}{l}0.046 * * \\
(0.016)\end{array}$ & \\
\hline Height $\times$ Father's education years & & & $\begin{array}{c}0.002 \\
(0.001)\end{array}$ \\
\hline Mother's education & $\begin{array}{c}-0.011 * * * \\
(0.002)\end{array}$ & & \\
\hline Mother is educated and urban & & $\begin{array}{c}-0.064 * \\
(0.025)\end{array}$ & \\
\hline Father's education & & & $\begin{array}{c}-0.005^{* *} \\
(0.002)\end{array}$ \\
\hline Observations & $2,232,895$ & $2,233,582$ & $2,140,583$ \\
\hline Infant mortality rate & 0.097 & 0.097 & 0.097 \\
\hline Mean height & 1.559 & 1.559 & 1.559 \\
\hline Mean mother's education (years) & 3.135 & & \\
\hline$\%$ sample educated and urban & & $12.80 \%$ & \\
\hline Mean father's education (years) & & & 4.612 \\
\hline
\end{tabular}

Robust standard errors clustered by country in brackets. Significant at $* * 5 \%, * * * 1 \%$. Controls include family demographics, education of both parents, and country $\times$ year fixed effects. Indicators of mother's socioeconomic status are interacted with mother's height in the specification in column 4 of table 2 ; see the notes to table 2 . See appendix table 1 in the supplementary material for the corresponding estimates with the nonlinear specification of mother's height.

Table 5.-Gradients: Interactions of Mother’s Height with Country-Cohort Level Indicators of Conditions in the Child’s Birth Year: Estimates With AND Without Mother FiXed EfFEcts

\begin{tabular}{|c|c|c|c|c|c|c|c|c|}
\hline & \multicolumn{2}{|c|}{ GDP } & \multicolumn{2}{|c|}{$\begin{array}{l}\text { Cohort Mother's } \\
\text { Education }\end{array}$} & \multicolumn{2}{|c|}{$\begin{array}{c}\text { DPT } \\
\text { Immunization Rate }\end{array}$} & \multicolumn{2}{|c|}{$\begin{array}{c}\text { Measles } \\
\text { Immunization Rate }\end{array}$} \\
\hline & No FE & $\mathrm{FE}$ & No FE & $\mathrm{FE}$ & No FE & $\mathrm{FE}$ & No FE & $\mathrm{FE}$ \\
\hline Mother's height & $\begin{array}{l}-0.409 * * * \\
(0.085)\end{array}$ & & $\begin{array}{l}-0.164 * * * \\
(0.007)\end{array}$ & & $\begin{array}{l}-0.159 * * * \\
(0.023)\end{array}$ & & $\begin{array}{l}-0.167 * * * \\
(0.02)\end{array}$ & \\
\hline Height $\times$ GDP & $\begin{array}{l}0.041 * * * \\
(0.011)\end{array}$ & $\begin{array}{c}0.117 \\
(0.077)\end{array}$ & & & & & & \\
\hline $\begin{array}{l}\text { Height } \times \text { Cohort mother's } \\
\text { education }\end{array}$ & & & $\begin{array}{l}0.020 * * * \\
(0.002)\end{array}$ & $\begin{array}{l}0.063 * * \\
(0.015)\end{array}$ & & & & \\
\hline Height $\times$ Immunization rate & & & & & $\begin{array}{l}0.096 * * \\
(0.037)\end{array}$ & $\begin{array}{l}0.130 * * \\
(0.057)\end{array}$ & $\begin{array}{l}0.109 * * \\
(0.034)\end{array}$ & $\begin{array}{l}0.123 * * \\
(0.054)\end{array}$ \\
\hline Observations & $2,233,720$ & $2,137,324$ & $2,233,720$ & $2,137,324$ & $1,496,468$ & $1,344,815$ & $1,496,468$ & $1,344,815$ \\
\hline Mean height & 1.559 & 1.559 & & & & & & \\
\hline IMR & 0.097 & 0.099 & & & & & & \\
\hline Mean mother's education & & & 3.093 & 3.051 & & & & \\
\hline DPT immunization rate & & & & & 0.603 & 0.591 & & \\
\hline Measles immunization rate & & & & & & & 0.601 & 0.588 \\
\hline
\end{tabular}

Robust standard errors clustered by country in brackets. Significant at $* * 5 \%, * * * 1 \%$. FE denotes mother fixed effects. Controls include family demographics and the education of both parents. The no-FE columns include country-year fixed effects, and the FE models include year dummies and country-specific trends, country dummies being absorbed by the mother fixed effects. See the notes to table 2. GDP is log per capita GDP. "Cohort mothers' education" refers to the average education of mothers giving birth in the child's year and country of birth. DPT and measles immunization rates are the lead of the rate achieved for children aged 12 to 23 months. GDP and mother's education are available for 38 countries from 1970 to 2000, and immunization rates are available for 37 countries from 1984 to 1999 . Appendix table 2 contains the corresponding estimates with the nonlinear specification of mother's height.

We find that it would fall by $19.4 \%$. The coefficient is three times as large conditional on mother fixed effects (table 5). There is, again, asymmetry and nonlinearity in the interactions effects (online appendix table 2). Our finding that marginal improvements in the average education of mothers in the child's birth cohort have a much larger impact than the same increase in the individual mother's education may indicate education externalities (Basu \& Foster, 1998).

Aggregate income shocks. The interaction term between income and mother's height indicates that a 1 stan- dard deviation increase in log per capita GDP (which is 0.744 ) produces a significant reduction of intergenerational persistence of $29.6 \%$ (table 5). There is some indication that income is more effective in weakening the intergenerational coefficient for short women (online appendix table 2). In the mother fixed effects specification, the income interaction coefficient is three times as large but loses significance as the standard errors are also inflated. However, once the fixed effects specification is extended to include indicators for height deviations, the interaction with income is significant for women with height 1 to 2 standard deviations 
Table 6.-Gradients: Interactions of Maternal Height with Country-Cohort Indicators of Conditions in the Child’s Fetal Year: Estimates WITH AND Without Mother FIXed EFFEcts

\begin{tabular}{|c|c|c|c|c|c|c|c|c|}
\hline & \multicolumn{2}{|c|}{ GDP } & \multicolumn{2}{|c|}{$\begin{array}{l}\text { Cohort Mother's } \\
\text { Education }\end{array}$} & \multicolumn{2}{|c|}{$\begin{array}{c}\text { DPT } \\
\text { Immunization Rate }\end{array}$} & \multicolumn{2}{|c|}{$\begin{array}{c}\text { Measles } \\
\text { Immunization Rate }\end{array}$} \\
\hline & No FE & FE & No FE & $\mathrm{FE}$ & No FE & $\mathrm{FE}$ & No FE & $\mathrm{FE}$ \\
\hline Mother's height & $\begin{array}{l}-0.410 * * * \\
(0.084)\end{array}$ & & $\begin{array}{l}-0.165^{* * *} \\
(0.020)\end{array}$ & & $\begin{array}{l}-0.156^{* * * *} \\
(0.024)\end{array}$ & & $\begin{array}{l}-0.157 * * * \\
(0.021)\end{array}$ & \\
\hline Height $\times$ GDP & $\begin{array}{l}0.041 * * * \\
(0.011)\end{array}$ & $\begin{array}{l}0.129 * \\
(0.075)\end{array}$ & & & & & & \\
\hline Height $\times$ Cohort mother's education & & & $\begin{array}{l}-0.020 * * * \\
(0.005)\end{array}$ & $\begin{array}{l}0.068 * * * \\
(0.017)\end{array}$ & & & & \\
\hline Height $\times$ Immunization rate & & & & & $\begin{array}{l}0.093 * * \\
(0.039)\end{array}$ & $\begin{array}{l}0.149 * * * \\
(0.039)\end{array}$ & $\begin{array}{l}0.096 * * \\
(0.037)\end{array}$ & $\begin{array}{l}0.111 * * * \\
(0.036)\end{array}$ \\
\hline Observations & $2,232,856$ & $2,137,234$ & $2,215,698$ & $2,118,829$ & $1,448,931$ & $1,249,171$ & $1,448,931$ & $1,249,171$ \\
\hline
\end{tabular}

below the mean. These results contribute some of the scarce evidence of the implications of income volatility for welfare (Pallage \& Robe, 2003).

Public health. A 1 standard deviation increase $(21.9 \%$ for DPT and $23.2 \%$ for measles) in immunization rates results in a $20 \%$ and $24.6 \%$ reduction, respectively, in the intergenerational correlation of health (table 5). Despite the public goods nature of immunization, we may expect stronger effects at the left tail, as this is where exposure to infectious disease is greatest. We find that attenuation is similar when comparing height either $0.5-1$ s.d. or 1-2 s.d. above and below the mean but beyond that, it is stronger for shorter women.

The fetal environment. Estimates for fetal year conditions $\left(y_{j t}\right)$ are of similar size and significance (table 6 and online appendix table 3). An adverse SES or public health environment in the fetal year lowers survival chances after birth, and these effects vary with the mother's stock of health. Previous estimates of the consequences of fetal health shocks do not allow impacts to vary with the mother's health (Almond \& Mazumder, 2009; Nilsson, 2008). This may contribute to explaining why earlier evidence that prenatal income shocks have an impact on fetal development is somewhat tenuous (see Cutler et al., 2007; Banerjee et al., 2007; and van den Berg, Doblhammer, \& Christensen, 2011), for early twentieth-century America, and nineteenth-century France and Denmark, respectively. ${ }^{9}$

\footnotetext{
${ }^{9}$ Having lent the estimates some interpretation, we should underline that fetal and birth year effects cannot be accurately distinguished with annual data. For children born in January, lagged conditions provide a better approximation of in utero conditions, but for children born in December, current conditions provide the better approximation. We used information on quarter of birth (as in Cutler et al., 2007, and Bhalotra, $2010 \mathrm{~b}$ ) to gain finer identification, but there was no qualitative change in the results. The timing problem arises in many similar studies. For example, among those cited here, Banerjee et al. (2007) appear to interpret effects for children born during the phylloxera crisis as in utero impacts, while van den Berg et al. (2009) interpret the effects of lagged conditions as in utero effects. At the very least, the similarity of our findings for current and lagged conditions indicates robustness of the main result (that early life conditions attenuate the intergenerational persistence of health) to the timing problem.
}

\section{Heterogeneity and Population-Averaged Effects}

The population-averaged effects in the levels model are almost identical to the baseline estimates that ignore heterogeneity in $\beta$ (see table 2 ). When the gradients model (equations [2a] and [2b]) is reestimated to allow $\beta$ and $\tau$ to be a function of (demeaned) mother-level characteristics, there is some evidence of heterogeneity in the gradients coefficients, for example, stronger gradients are evident for girl births, higher-order births, and mothers younger at birth. The uninteracted coefficients $\beta$ and $\tau$ are nevertheless not significantly different from the coefficients obtained from the more restrictive model that does not allow slope heterogeneity, which suggests that the heterogeneity is uncorrelated with the treatment (online appendix tables 4A and 4B). ${ }^{10}$

\section{E. Longer-Run Economic Development}

We estimated equation (1) for birth cohorts 1970-1975 and 1990-1995 separately for countries with positive growth of at least $1.5 \%$ per annum, countries with negative growth of at least $1.5 \%$, and countries with insignificant growth, where growth is the average linear rate over the entire period (table 1). The idea is to investigate the effects of longer-run economic growth, which wraps together education, income, and public health. We find that there is no statistically significant difference in the intergenerational coefficient between 1970-1975 and 1990-1995 in countries that experienced statistically significant positive growth or countries for whom growth or regression was insignificant (Table 7), while in the regressing group, the intergenerational correlation coefficient rises. An alternative way of assessing the longer-run impact of economic development is to study the relationship between the country-specific $\beta_{0 \mathrm{j}}$ and average log country GDP per capita over the period (figure 3). A linear fit has a

\footnotetext{
${ }^{10}$ Most of the gradients coefficients fall slightly, but the immunization coefficients fall more than slightly, to half their former size (online appendix table 4a). However the new coefficients are not significantly different from the original coefficents reported in tables 4 and 5. Moreover, once we allow nonlinearity in the effect of mother's height, the significance of the immunization gradient is restored (online appendix table 4B).
} 
Table 7.-Estimates for Polarized Cohorts in Growing, Regressing, and Stagnating Countries

\begin{tabular}{|c|c|c|c|c|c|c|}
\hline & \multicolumn{2}{|c|}{ Growth $>1.5 \%$ Per Annum } & \multicolumn{2}{|c|}{ Growth $<-1.5 \%$ Per Annum } & \multicolumn{2}{|c|}{ Insignificant Growth } \\
\hline & 1970-1975 & 1990-1995 & 1970-1975 & 1990-1995 & 1970-1975 & 1990-1995 \\
\hline Height & $\begin{array}{c}-0.091 * * * \\
(0.023)\end{array}$ & $\begin{array}{c}-0.096^{* * * *} \\
(0.009)\end{array}$ & $\begin{array}{c}-0.091 * * \\
(0.040)\end{array}$ & $\begin{array}{c}-0.114 * * * \\
(0.018)\end{array}$ & $\begin{array}{c}-0.091 * * \\
(0.028)\end{array}$ & $\begin{array}{c}-0.091 * * * \\
(0.012)\end{array}$ \\
\hline Observations & 65,796 & 256,650 & 17,495 & 73,233 & 37,342 & 16,2545 \\
\hline IMR & 0.140 & 0.073 & 0.110 & 0.085 & 0.131 & 0.103 \\
\hline Mean height & 1.547 & 0.155 & 1.554 & 1.552 & 1.584 & 1.588 \\
\hline
\end{tabular}

Robust standard errors in brackets, allowing for clustering within country. Significant at $* * 5 \%, * * * 1 \%$. See table 1 for growth rates. Countries with growth greater than 1.5\% are Egypt, Lesotho, Morocco, Mali, Colombia, Dominican Republic, India, and Turkey. Countries with negative growth greater than 1.5\% are Gabon, Madagascar, Togo, Zambia, Nicaragua, and Cambodia. Countries with insignificant growth are Benin, Cameroon, Chad, Comoros, Cote d'Ivoire, Ghana, Guinea, Mozambique, Namibia, Rwanda, Senegal, Tanzania, Uganda, Zimbabwe, and Haiti. Countries that are in none of these samples are Brazil, Burkina Faso, Central African Republic, Ethiopia, Honduras, Kenya, Malawi, Niger, Peru.

Figure 3.-Country-Specific Marginal Effects against Average Log GDP

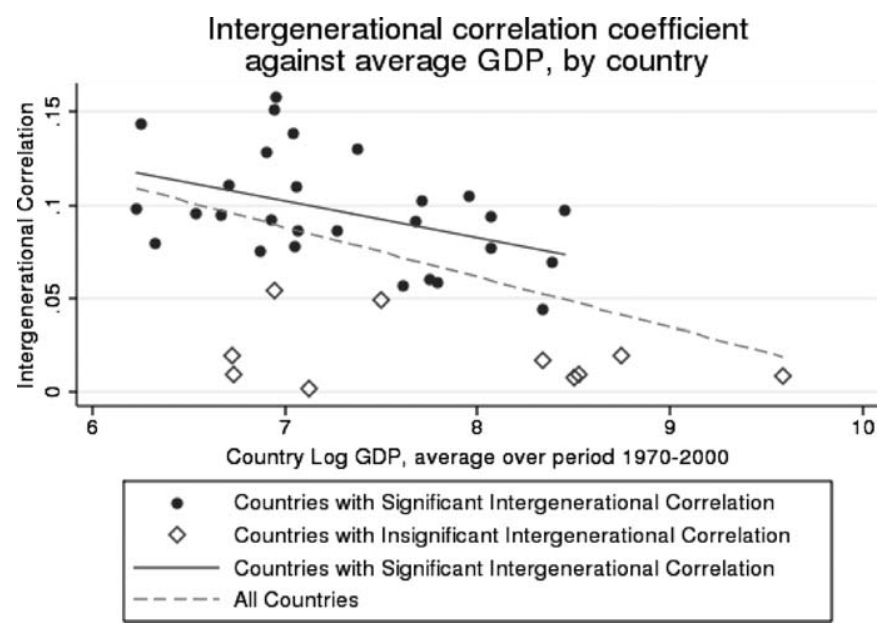

The $38 \beta_{0 j}$ estimated from equation (1a) are plotted against average GDP from 1970 to 2000.

slope of $-0.027(t=3.34)$. The reason that we do not consider long-range growth in our main specification is that it is potentially confounded with other changes, such as medical technological progress, that may be correlated with child health (Deaton \& Paxson, 2004). Our strategy has therefore been to control for the main effects of growth and other unobservable trends at the country level while looking for the potential for plausibly exogenous variation in income, education, and immunization rates to tilt the relationship between mother's height and infant mortality risk.

\section{Conclusion}

This paper contributes to a small literature on the intergenerational transmission of health and a smaller literature on its gradient. Using harmonized microdata from across developing countries on births over three decades, it investigates how changes in the socioeconomic environment that the child is born into alter the gradient of the intergenerational correlation and how these gradients vary along the distribution of mother's health. It uses a micropanel nested in a macropanel to purge unobserved heterogeneity at the mother and country-year levels and further investigates mother-level heterogeneity in the gradient.
Our finding that maternal stature has a substantial negative influence on infant survival across countries contributes to evidence that adult height is an indicator of health (Case $\&$ Paxson, 2010). Other studies have shown that adult height is sensitive to the childhood environment (Deaton, 2007; Bhalotra, 2008; Akresh et al., 2012). This, together with our finding that children of shorter mothers are more sensitive to changes in the socioeconomic environment, suggests that the intergenerational transmission of health involves not only genomic but also nongenomic mechanisms. Our results effectively constitute some of the scarce evidence of intergenerational multiplier effects of improvements in the early life environment (see Fung \& Wei, 2009).

The importance of maternal health during pregnancy is well established, hence the common focus on smoking and alcohol consumption during pregnancy (Almond \& Currie, 2010). Our results suggest a wider focus, showing that the mother's stock of health, accumulation of which begins at her birth (Deaton, 2007; Bhalota, 2007; Bozzoli et al., 2009), is relevant to the health and life chances of her offspring. This is pertinent in developing countries, where there tends to be systematic underinvestment in the health of girls from the start (Bharadwaj \& Nelson, 2010; Jayachandran \& Kuziemko, 2009; Oster, 2009). We show that, taking the stock of maternal health as given at the birth of the child, investments in mother's education, economic growth, and public health provision all work to limit the extent to which children born to shorter women are condemned to poorer health and thereby poorer living standards in the long run. The findings defend the increasing prevalence of the view that government policies to promote early accumulation of human capital should be targeted to children of disadvantaged families (Cunha \& Heckman, 2007). They contribute unique evidence on an important and understudied aspect of persistent inequality in developing countries, where underdeveloped markets and states result in children often being unable to escape from the family circumstances that they are born into.

\section{REFERENCES}

Ahlburg, D., (1998), "Intergenerational Transmission of Health," The American Economic Review 88 (1998), 265-270.

Akresh, R., Bhalotra, S., Leone, M., and Osili, U., "War and Stature: Growing Up during the Nigerian Civil War," American Economic Review Papers and Proceedings 102 (2012), 273-277. 
Almond, D., "Is the 1918 Influenza Pandemic Over? Long-Term Effects of In Utero Influenza Exposure in the Post-1940 U.S. Population," Journal of Political Economy 114 (2006), 672-712.

Almond, D., \& Chay, K., "The Long-Run and Intergenerational Impact of Poor Infant Health: Evidence from Cohorts Born during the Civil Rights Era," mimeograph (2006).

Almond, D., Chay, K., and Lee, S., "The Costs of Low Birthweight," Quarterly Journal of Economics 120 (2005), 1031-1083.

Almond, D., and Currie, J., "Human Capital Development before Age Five," NBER working paper 15827 (2010).

Almond, D., and Mazumder, B., "Health Capital and the Prenatal Environment: The Effect of Maternal Fasting during Pregnancy," Federal Reserve Bank of Chicago working paper 2007-22 (2008).

Baird, S., Friedman, J., and Schady, N., “Aggregate Income Shocks and Infant Mortality in the Developing World," this REVIEW 93 (2011), $847-856$.

Banerjee, A., Duflo, E., Postel-Vinay, G., and Watts, T. M., "Long-Run Health Impacts of Income Shocks: Wine and Phylloxera in 19thCentury France," this REVIEW 92 (2007), 714-728.

Barker, D. J. P., "Maternal Nutrition, Fetal Nutrition and Diseases in Later Life," Nutrition 13 (1997), 807-813.

Basu, K., Analytical Development Economics (Cambridge, MA: MIT Press, 1997).

Basu, K., and Foster, J., "On Measuring Literacy," Economic Journal 108 (1998), 1733-1749.

Becker, G. S., and Tomes, N., "An Equilibrium Theory of the Distribution of Income and Intergenerational Mobility," Journal of Political Economy 87 (1979), 1153-1189.

"Human Capital and the Rise and Fall of Families," Journal of Labor Economics 4 (1986), S1-S39.

Behrman, J. R., and Rosenzweig, M. R., "Does Increasing Women's Schooling Raise the Schooling of the Next Generation?" American Economic Review 92 (2002), 323-334.

Bertrand, M., Duflo, E., and Mullainathan, S., "How Much Should We Trust Differences-in-Differences Estimates?" Quarterly Journal of Economics 119 (2004), 249-275.

Bhalotra, S., "Spending to Save? State Health Expenditure and Infant Mortality in India," Health Economics 16 (2007), 911-928.

"Wuthering Heights: Birth Shocks and Stature amongst Indian Men and Women," paper presented at the European Society of Population Economics University of Bristol (2008).

"Reproductive Mortality: The Very Long Arm of Childhood," paper presented the AEA meetings, Denver, CO (2011a).

"Fatal Fluctuations? Cyclicality in Infant Mortality in India," Journal of Development Economics (2010b), 7-19.

Bhalotra, S., and Rawlings, S. B., "Intergenerational Persistence in Health in Developing Countries: The Penalty of Gender Inequality?" Journal of Public Economics 95 (2011), 286-299.

Bharadwaj, P., and Nelson, L., "Discrimination Begins in the Womb: Evidence of Sex-Selective Prenatal Investments," mimeograph, University of San Diego (2010).

Björklund, A., Lindahl, M., and Plug, E., "The Origins of Intergenerational Associations: Lessons from Swedish Adoption Data," Quarterly Journal of Economics 121 (2006), 999-1028.

Black, R., and Morris, S. B. J. "Where and Why Are 10 Million Children Dying Every Year?" Lancet 36 (2003), 2226-2234.

Black, S., and Devereux, P., "Recent Developments in Intergenerational Mobility," NBER working paper 15889 (2010).

Black, S., Devereux, P., and Salvanes, K., "Why the Apple Doesn't Fall Far: Understanding Intergenerational Transmission of Human Capital," American Economic Review 95 (2005), 437-449.

Bound, J., and Solon, G., "Double Trouble: On the Value of Twins-Based Estimation of the Return to Schooling," Economics of Education Review 18 (1999), 169-182.

Bozolli, C., Deaton, A., and Quintana-Domeque, C., "Adult Height and Childhood Disease," Demography (2009), 647-669.

Camacho, A., "Stress and Birth Weight: Evidence from Terrorist Attacks," Papers and Proceedings of the One Hundred Twentieth Annual Meeting of the American Economic Association 98 (2008), 511-515.

Case, A., Fertig, A., and Paxson, C., "The Lasting Impact of Childhood Health and Circumstance," Journal of Health Economics (2005), $365-389$.
Case, A., Lubotsky, D., and Paxson, C., "Economic Status and Health in Childhood: The Origins of the Gradient," American Economic Review (2002), 1308-1334.

Case, A., and C. Paxson, "Causes and Consequences of Early-Life Health," Demography 47 (2010), 565-585.

Case, Anne, Christina Paxson, and Joseph Ableidinger, "Orphans in Africa: Parental Death, Poverty, and School Enrollment," Demography 41 (2004), 483-508.

Cawley, R., Mckeown, T., and Record, R., "Parental Stature and Birth Weight," Annals of Human Genetics 6 (1954), 448-456.

Chaudhury, N., Hammer, J., Kremer, M., and Muralidharan, K., "Missing in Action: Teacher and Health Worker Absence in Developing Countries," Journal of Economic Perspectives (2006), 91-116.

Chevalier, A., "Parental Education and Child's Education: A Natural Experiment," mimeograph, University College Dublin (2003).

Cole, T. J., "Secular Trends in Growth," Proceedings of the Nutrition Society 59 (2000), 317-324.

Cogswell, M., Weisberg, P., and Spong, C., "Cigarette Smoking, Alcohol Use and Adverse Pregnancy Outcomes: Implications for Micronutrient Supplementation," Journal of Nutrition 133 (2003), 1722S1731 S.

Conley, D., and Bennett, N. G., "Birth Weight and Income: Interactions across Generations," Journal of Health and Social Behavior 42 (2001), 450-465.

Corak, M., "Do Poor Children Become Poor Adults? Lessons from a Cross Country Comparison of Generational Earnings Mobility," (pp. 143-148), in J. Creedy and G. Kalb (eds.), Dynamics of Inequality and Poverty: Research on Economic Inequality (New York: Elsevier, 2006).

Costa, D. L., "Unequal at Birth: A Long-Term Comparison of Income and Birth Weight," Journal of Economic History 58 (1998), 987-1009.

Cunha, F., and Heckman, J. J., "The Technology of Skill Formation," IZA discussion paper 2550 (2007).

Currie, J., "Healthy, Wealthy, and Wise: Socioeconomic Status, Poor Health in Childhood, and Human Capital Development," Journal of Economic Literature 47 (2009), 87-122.

Currie, J., and Moretti, E., "Mother's Education and the Intergenerational Transmission of Human Capital: Evidence from College Openings," Quarterly Journal of Economics 118 (2003), 1495-1532.

Currie, J., and Moretti, E., "Biology as Destiny? Short- and Long-Run Determinants of Intergenerational Transmission of Birth Weight," Journal of Labor Economics 25 (2007), 231-264.

Cutler, D., Deaton, A., and Lleras-Muney, A "The Determinants of Mortality," Journal of Economic Perspectives 20 (2006), 97-120.

Cutler, D., and A. Lleras-Muney, "Education and Health: Evaluating Theories and Health," NBER working paper 12352 (2006).

Cutler, D., Miller, G., and Norton, D. M., "Evidence on Early-Life Income and Late-Life Health from America's Dust Bowl Era," Proceedings of the National Academy of Sciences 104 (2007), 13244-13249.

Datar, A., Ghosh, A., and Sood, N., "Mortality Risks, Health Endowments, and Parental Investments in Infancy: Evidence from Rural India," NBER working paper W13649 (2007).

Dasgupta, P., and Ray, D., "Inequality as a Determinant of Malnutrition and Unemployment: Policy," Economic Journal 97 (1987), 177-188.

Deaton, A., "Global Patterns of Income and Health: Facts, Interpretations and Policies," WIDER annual lecture, Helsinki (2006).

"Height, Health and Development," Proceedings of the National Academy of Science 104 (2007), 13232-13237.

"Instruments, Randomization, and Learning about Development," Journal of Economic Literature 48 (2010), 424-455.

Deaton, A., and Paxson, C., "Mortality, Income, and Income Inequality over Time in Britain and the United States" (pp. 247-280), in David A. Wise (ed.), Perspectives on the Economics of Aging (Chicago: University of Chicago Press, 2004).

Dehejia, R., and Lleras-Muney, A., "Booms, Busts and Babies' Health," Quarterly Journal of Economics 119 (2004), 1091-1130.

Drake, A. J., and Walker, B. R., "The Intergenerational Effects of Fetal Programming: Nongenomic Mechanisms for the Inheritance of Low Birth Weight and Cardiovascular Risk," Journal of Endocrinology 180 (2004), 1-16.

Elo, I. T., and Preston, S. H., "Effects of Early-Life Conditions on Adult Mortality: A Review," Population Index, 58 (1992), 186-212.

Emmanuel, I., Filakti, H., Alberman, E., and Evans, S., "Intergenerational Studies of Human Birth Weight from the 1958 Birth Cohort. I. 
Evidence for a Multigenerational Effect," British Journal of Obstetrics and Gynaecology 99 (1992), 67-74.

Fogel, R., "Economic Growth, Population Theory, and Physiology: The Bearing of Long-Term Processes on the Making of Economic Policy," American Economic Review 84 (1994), 369-395.

Fung, W., and Wei, H., "Intergenerational Effects of the 1959-61 China Famine," mimeograph, Harvard University (2009).

Galton, F., "Regression towards Mediocrity in Hereditary Stature," Journal of the Anthropological Institute of Great Britain and Ireland 15 (1886), 246-263.

Grawe, N., "Reconsidering the Use of Non-Linearities in Intergenerational Earnings Mobility as a Test for Credit Constraints," Journal of Human Resource 39 (2004), 813-827.

Grawe, N. D., and Mulligan, C. B., "Economic Interpretations of Intergenerational Correlations," Journal of Economic Perspectives 16 (2002), 45-58.

Hackman, E., Emanuel, I., van Belle, G., and Daling, J., "Maternal Birth Weight and Subsequent Pregnancy Outcome," Journal of the American Medical Association 250 (1983), 2016-2019.

Heckman, J. J., "Causal Parameters and Policy Analysis in Economics: A Twentieth Century Retrospective," Quarterly Journal of Economics 115 (2000), 45-97.

Heckman, J., "The Economics, Technology, and Neuroscience of Human Capability Formation," PNAS 104 (2007), 13250-13255.

Ibáñez, L., Ferrer, A., Marcos, M., Hierro, F., and Zegher, F., "Early Puberty: Rapid Progression and Reduced Final Height in Girls with Low Birth Weight," Pediatrics 106 (2000), e72.

Isiugo-Abanihe, U. C., "Child Fosterage in West Africa," Population and Development Review 11 (1985), 53-73.

Jayachandran, S., and Kuziemko, I., "Why Do Mothers Breastfeed Girls Less Than Boys? Evidence and Implications for Child Health in India," NBER working paper 15041 (2009).

Klebanoff, M., N. Secher, B. Mednick, and C. Schulsinger, "Maternal Size at Birth and the Development of Hypertension during Pregnancy," Archives of Internal Medicine 159 (1999), 1607-1612.

Koren, M., and Tenreyo, S., "Volatility and Development," Quarterly Journal of Economics 122 (2007), 243-287.

Kramer, M., "Determinants of Low Birth Weight: Methodological Assessment and Meta-Analysis," Bulletin of the World Health Organisation 65 (1987), 663-737.

Malik, A., and Temple, J. R. W., "The Geography of Output Volatility," Journal of Development Economics 90 (2009), 163-178.

Macgregor, S., B. K. Cornes, N. G. Martin, and P. M. Visscher, "Bias, Precision, and Heritability of Self-Reported and Clinically Measured Heght in Australian Twins," Human Genetics 120 (2006), 571-580.

Miller, G., and Urdinola, P., "Cyclicality, Mortality, and the Valve of Time: The Case of Coffee Price Fluctuations and Child Survival in Colombia," Journal of Political Economy (with Piedad Urdinola). 118 (2010), 113-155.

Moffitt, T. E., Caspi, A., and Rutter, M., "Strategy for Investigating Interaction between Measured Genes and Measured Environments," Archives of General Psychiatry 62 (2005), 473-481.

Nilsson, P., "Does a Pint a Day Affect Your Child's Pay? The Effect of Prenatal Alcohol Exposure on Adult Outcomes," CeMMAP working paper CWP22/08 (2008).

Osili, U., "Does Female Schooling Affect Fertility? Evidence from Nigeria," Journal of Development Economics 87 (2008), 57-75.

Oster, E., "Proximate Causes of Population Gender Imbalance in India," Demography 46 (2009), 325-340.

Pallage, S., and Robe, M., "On the Welfare Cost of Economic Fluctuations in Developing Countries," International Economic Review 44 (2003), 677-698.

Paxson, C., and Schady, N., "Child Health and Economic Crisis in Peru," World Bank Economic Review 19 (2005), 203-223.

Plug, E., "Estimating the Effect of Mother's Schooling on Children's Schooling Using a Sample of Adoptees," American Economic Review 94 (2004), 358-368.
Pritchett, L., "Understanding Patterns of Economic Growth: Searching for Hills Among Plateaus, Mountains, and Plains," World Bank Econamic Review 14 (2000), 221-250.

Royer, H., "Separated at Girth: U.S. Twin Estimates of the Long-Run and Intergenerational Effects of Fetal Nutrients," American Economic Journal_Applied Economics 1 (2009), 49-85.

Sacerdote, B., "The Nature and Nurture of Economic Outcomes," American Economic Review 92 (2002), 344-348.

Schultz, T. P., "Productive Benefits of Health: Evidence from LowIncome Countries," in G. Lopez-Casasnovas, Berta Riveras, and L. Currais (eds.), Health and Economic Growth: Findings and Policy Implications (Cambridge, MA: MIT Press, 2005).

Smith, J," "The Impact of Childhood Health on Adult Labor Market Outcomes," this REVIEW 91 (2009), 478-489.

Solon, G., "Intergenerational Income Mobility in the United States," American Economic Review 82 (1992), 393-408.

"Cross-Country Differences in Intergenerational Earnings Mobility," Journal of Economic Perspectives 16 (2002), 59-66. "A Model of Intergenerational Mobility Variation over Time and Place," in Miles Corek (ed.), Generational Income Mobility in North America and Europe (Cambridge: University Press, 2004)

Steckel, R. H., "A Peculiar Population: the Nutrition, Health, and Mortality of American Slaves from Childhood to Maturity," Journal of Economic History 46 (1986), 721-741.

"Stature and the Standard of Living," Journal of Economic Literature 33 (1995), 1903-1940.

Strauss, J., and Thomas, D., "Health over the Life Course" (pp. 33753465), in T. Paul Schultz and John Strauss (eds.), Handbook of Development Economics (Elsevier, 2008).

Thomas, D., and Strauss, J., "Health and Wages: Evidence on Men and Women in Urban Brazil," Journal of Econometrics 77 (1997), 159-185.

Turkheimer, E., Haley, A, Waldron, M., D’Onofrio, B., and Gottesman, I. "Socioeconomic Status Modifies Heritability of IQ in Young Children," Psychological Science (2003), 623-628.

UNICEF, "Immunization Summary, A Statistical Reference Containing Data Through 2007” (2009), http://www.childinfo.org/files /Immunization_Summary_2009.pdf.

van den Berg, G. J., Doblhammer, G., and Christensen, K., "Being Born under Adverse Economic Conditions Leads to a Higher Cardiovascular Mortality Rate Later in Life: Evidence Based on Individuals Born at Different Stages of the Business Cycle," Demography 48:2 (2011), 507-530.

van den Berg, G. J., Lindeboom, M., and Lopez, M., "Economic Conditions Early in Life and Individual Mortality," American Economic Review 96 (2006), 290-302.

"Exogenous Determinants of Early-Life Conditions, and Mortality Later in Life," Social Science \& Medicine 68 (2009), 15911598

Venkataramani, A. S., "The Intergenerational Transmission of Height: Evidence from Rural Vietnam," Health Economics 20 (2011) $1448-1467$.

Waaler, H. T., "Height, Weight, and Mortality: The Norwegian Experience," Acta Medica Scandinavica 77 (1984), 279-303.

WHO, The World Health Report 1995: Bridging the Gaps (Geneva: WHO, 1995).

Wooldridge, J. M., Econometric Analysis of Cross Section and Panel Data (Cambridge, MA: MIT Press, 2002)

"Fixed-Effects and Related Estimators for Correlated RandomCoefficient and Treatment-Effect Panel Data Models," this REvIEW 82 (2005a), 385-390.

"Unobserved Heterogeneity and Estimation of Average Partial Effects," in D. Andrews and J. Stock (eds.), Identification and Inference for Econometric Models: A Festschrift in Honor of Thomas J. Rothenberg (Cambridge: Cambridge University Press, 2005b). 